\title{
Front Matter: Volume 7035
}

, "Front Matter: Volume 7035," Proc. SPIE 7035, Biosensing, 703501 (29 September 2008); doi: 10.1117/12.806033

SPIE Event: NanoScience + Engineering, 2008, San Diego, California, United SPIE. States 


\title{
PROCEEDINGS OF SPIE
}

\section{Biosensing}

\author{
Manijeh Razeghi \\ Hooman Mohseni \\ Editors
}

12-14 August 2008

San Diego, California, USA

Sponsored and Published by

SPIE

Volume 7035

Proceedings of SPIE, 0277-786X, v. 7035 
The papers included in this volume were part of the technical conference cited on the cover and title page. Papers were selected and subject to review by the editors and conference program committee. Some conference presentations may not be available for publication. The papers published in these proceedings reflect the work and thoughts of the authors and are published herein as submitted. The publisher is not responsible for the validity of the information or for any outcomes resulting from reliance thereon.

Please use the following format to cite material from this book:

Author(s), "Title of Paper," in Biosensing, edited by Manijeh Razeghi, Hooman Mohseni, Proceedings of SPIE Vol. 7035 (SPIE, Bellingham, WA, 2008) Article CID Number.

ISSN 0277-786X

ISBN 9780819472557

Published by

SPIE

P.O. Box 10, Bellingham, Washington 98227-0010 USA

Telephone +1 3606763290 (Pacific Time) · Fax +1 3606471445

SPIE.org

Copyright (C 2008, Society of Photo-Optical Instrumentation Engineers

Copying of material in this book for internal or personal use, or for the internal or personal use of specific clients, beyond the fair use provisions granted by the U.S. Copyright Law is authorized by SPIE subject to payment of copying fees. The Transactional Reporting Service base fee for this volume is $\$ 18.00$ per article (or portion thereof), which should be paid directly to the Copyright Clearance Center (CCC), 222 Rosewood Drive, Danvers, MA 01923. Payment may also be made electronically through CCC Online at copyright.com. Other copying for republication, resale, advertising or promotion, or any form of systematic or multiple reproduction of any material in this book is prohibited except with permission in writing from the publisher. The CCC fee code is $0277-786 \mathrm{X} / 08 / \$ 18.00$.

Printed in the United States of America.

Publication of record for individual papers is online in the SPIE Digital Library.

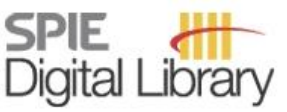

SPIEDigitallibrary.org

Paper Numbering: Proceedings of SPIE follow an e-First publication model, with papers published first online and then in print and on CD-ROM. Papers are published as they are submitted and meet publication criteria. A unique, consistent, permanent citation identifier (CID) number is assigned to each article at the time of the first publication. Utilization of CIDs allows articles to be fully citable as soon they are published online, and connects the same identifier to all online, print, and electronic versions of the publication. SPIE uses a six-digit CID article numbering system in which:

- The first four digits correspond to the SPIE volume number.

- The last two digits indicate publication order within the volume using a Base 36 numbering system employing both numerals and letters. These two-number sets start with 00, 01, 02, 03, 04, 05, $06,07,08,09,0 A, 0 B \ldots 0 Z$, followed by $10-12,20-2 Z$, etc.

The CID number appears on each page of the manuscript. The complete citation is used on the first page, and an abbreviated version on subsequent pages. Numbers in the index correspond to the last two digits of the six-digit CID number. 


\section{Contents}

vii Conference Committee

ix Revivals of molecular nonlinear optics in physics, chemistry, and life sciences (Plenary Paper) [7040-100]

J. Zyss, Lab. de Photonique Quantique et Moléculaire, CNRS, Institut d'Alembert (France)

\section{SESSION 1 ADVANCES IN SURFACE PLASMON RESONANCE}

703503 Development of plasmonic substrates for biosensing (Invited Paper) [7035-02]

A. G. Brolo, J. Ferreira, M. J. L. Santos, C. Escobedo, D. Sinton, Univ. of Victoria (Canada); E. M. Girotto, Univ. Estadual de Maringa (Brazil); F. Eftekhari, R. Gordon, Univ. of Victoria (Canada)

703504 Plasmonic nanohole arrays for real-time multiplex biosensing (Invited Paper) [7035-03] A. Lesuffleur, H. Im, N. C. Lindquist, K. S. Lim, S.-H. Oh, Univ. of Minnesota, Twin Cities (United States)

703505 Parallel microfluidic arrays for SPRi detection (Invited Paper) [7035-04] E. Ouellet, Univ. of British Columbia (Canada); C. Lausted, L. Hood, Institute for Systems Biology (United States); E. T. Lagally, The Univ. of British Columbia (Canada)

\section{SESSION 2 BIOMIMITATION}

703508 Patterning and characterization of model phospholipid membranes [7035-07]

A. Kassu, F. A. Calzzani, Jr., J. M. Taguenang, R. K. Sileshi, A. Sharma, Alabama A\&M Univ. (United States)

703509 Automatable lipid bilayer formation for ion channel studies (Invited Paper) [7035-08] J. L. Poulos, H. Bang, T.-J. Jeon, J. J. Schmidt, Univ. of California, Los Angeles (United States)

7035 OA Electrokinetic delivery of single fluorescent biomolecules in fluidic nanochannels [7035-09] L. M. Davis, B. K. Canfield, X. Li, W. H. Hofmeister, G. Shen, I. P. Lescano-Mendoza,

B. W. Bomar, Univ. of Tennessee Space Institute (United States); J. P. Wikswo, D. A. Markov, P. C. Samson, Vanderbilt Univ. (United States); C. Daniel, Oak Ridge National Lab. (United States); Z. Sikorski, W. N. Robinson, Univ. of Tennessee Space Institute (United States)

\section{SESSION $3 \quad$ BIOSENSORS I}

7035 OE Giant magnetoresistive biosensors for molecular diagnosis: surface chemistry and assay development [7035-14]

H. Yu, S. J. Osterfeld, Magarray, Inc. (United States); L. Xu, Stanford Univ. (United States); R. L. White, Magarray, Inc. (United States); N. Pourmand, Univ. of California, Santa Cruz (United States); S. X. Wang, Stanford Univ. (United States) 
7035 OF Cancer monitoring with nanoparticles and microfluidics (Invited Paper) [7035-15]

S. Esener, I. Ortac, S. Zlatanovic, Y. T. Liu, D. Carson, Univ. of California, San Diego (United States)

\section{SESSION 4 DNA I}

$7035 \mathrm{OH} \quad$ DNA-templated nanowires as sacrificial materials for creating nanocapillaries (Invited Paper) [7035-17]

J. T. Stewart, Brigham Young Univ. (United States); H. A. Becerril, Stanford Univ. (United

States); W. Yang, M. G. Larsen, A. T. Woolley, Brigham Young Univ. (United States)

7035 Ol Integration of molecular structures in electrode gaps by dielectrophoresis (Invited Paper) [7035-18]

A. Csáki, St. Berg, Ch. Leiterer, Institute of Photonic Technology (Germany); R. Kretschmer, Jenaer Biochip Initiative (Germany); A. Wolff, W. Fritzsche, Institute of Photonic Technology (Germany)

7035 0J Single and double stranded DNA detection using locked nucleic acid (LNA) functionalized nanoparticles [7035-19]

F. McKenzie, R. Stokes, K. Faulds, D. Graham, Univ. of Strathclyde (United Kingdom)

\section{SESSION 5 DNA II}

7035 OL DNA-programmed protein-nanoelectronic transducer array (Invited Paper) [7035-21]

G. Withey, J. H. Kim, J. Xu, Brown Univ. (United States)

7035 ON Direct concentration of circulating DNA by using a nanostructured tip [7035-23]

W.-H. Yeo, J.-H. Chung, Univ. of Washington (United States); Y. Liu, Univ. of Texas at Arlington (United States); K.-H. Lee, NanoFacture, Inc. (United States)

\section{SESSION $6 \quad$ BIOSENSORS II}

703500 Wireless integrated microsystems for monitoring brain chemical and electrical activity (Invited Paper) [7035-24]

M. Roham, Case Western Reserve Univ. (United States); P. A. Garris, Illinois State Univ. (United States); P. Mohseni, Case Western Reserve Univ. (United States)

$70350 Q \quad$ Simultaneous wireless electrophysiological and neurochemical monitoring (Invited Paper) [7035-26]

K. Murari, M. Mollazadeh, N. Thakor, Johns Hopkins Univ. School of Medicine (United States);

G. Cauwenberghs, Univ. of California, San Diego (United States)

7035 OT Grating-based nanophotonic structured configurations for biosensing [7035-29]

I. Abdulhalim, M. Auslender, S. Hava, Ben-Gurion Univ. of the Negev (Israel) 
7035 OV A bio-inspired single photon detector with suppressed noise and low jitter (Invited Paper) [7035-31]

O. G. Memis, A. Katsnelson, H. Mohseni, Northwestern Univ. (United States); M. Yan, S. Zhang, T. Hossain, N. Jin, I. Adesida, Univ. of Illinois at Urbana-Champaign (United States)

7035 OW Design and fabrication of an omnidirectional reflector as ultra-sensitive biochemical sensing platform [7035-32]

J. Gao, A. Widjaja, M. Pan, A. Sarangan, Q. Zhan, Univ. of Dayton (United States)

7035 0X Tolerance analysis of a micro-optical detection unit for fluorescence and absorbance measurements in lab-on-a-chip micro-channels for chromatographic applications [7035-33]

S. Van Overmeire, H. Ottevaere, G. Desmet, H. Thienpont, Vrije Univ. Brussel (Belgium)

7035 OY Bioadhesive nanoareas in antifouling matrix for highly efficient affinity sensors [7035-34] I. Mannelli, A. Valsesia, P. Lisboa, Institute for Health and Consumer Protection (Italy); M. Anger-Leroy, GenOptics SA (France); S. Mornet, Condensed Matter Chemistry Institute of Bordeaux, CNRS (France); P. Colpo, F. Rossi, Institute for Health and Consumer Protection (Italy)

$70350 Z$ Bio-inspired target detection in natural scenes: optimal thresholds and ego-motion [7035-42]

S. D. Wiederman, R. S. A. Brinkworth, D. C. O'Carroll, The Univ. of Adelaide (Australia)

SESSION 8 BIOSENSORS III

703510 A low-power imager and compression algorithms for a brain-machine visual prosthesis for the blind (Invited Paper) [7035-35]

L. Turicchia, M. O'Halloran, D. P. Kumar, R. Sarpeshkar, Massachusetts Institute of Technology (United States)

703514 Towards reliable multi-pathogen biosensors using high-dimensional encoding and decoding techniques (Invited Paper) [7035-39]

S. Chakrabartty, Y. Liu, Michigan State Univ. (United States)

Author Index 
Downloaded From: https://www.spiedigitallibrary.org/conference-proceedings-of-spie on 26 Apr 2023

Terms of Use: https://www.spiedigitallibrary.org/terms-of-use 


\title{
Conference Committee
}

\author{
Symposium Chairs
}

David L. Andrews, University of East Anglia Norwich (United Kingdom) James G. Grote, Air Force Research Laboratory (United States)

Kevin J. Liddane, Oerlikon Optics USA, Inc. (United States)

Conference Chairs

Manijeh Razeghi, Northwestern University (United States)

Hooman Mohseni, Northwestern University (United States)

Program Committee

Gert Cauwenberghs, University of California San Diego (United States)

Philippe M. Fauchet, University of Rochester (United States)

David H. Gracias, Johns Hopkins University (United States)

Kimberly Hamad-Schifferli, Massachusetts Institute of Technology (United States)

Sean Humbert, University of Maryland, College Park (United States)

Giacomo Indiveri, ETH Zürich (Switzerland)

Eric Lagally, University of British Columbia (Canada)

Chang Liu, Northwestern University (United States)

Yuhwa Lo, University of California, San Diego (United States)

Heather D. Maynard, University of California, Los Angeles (United States)

Ryan P. McClintock, Northwestern University (United States)

Masoud Panjehpour, Thompson Cancer Survival Center (United States)

Tadashi Shibata, The University of Tokyo (Japan)

Donald J. Silversmith, Air Force Office of Scientific Research (United States)

Marija Strojnik, Centro de Investigaciones en Óptica, A.C. (Mexico)

Din Ping Tsai, National Taiwan University (Taiwan)

Adam T. Woolley, Brigham Young University (United States)

\section{Session Chairs}

1 Advances in Surface Plasmon Resonance

Kimberly Hamad-Schifferli, Massachusetts Institute of Technology (United States)

Eric Lagally, University of British Columbia (Canada) 
Eric Lagally, University of British Columbia (Canada)

3 Biosensors 1

David H. Gracias, Johns Hopkins University (United States)

Hitoshi Tabata, The University of Tokyo (Japan)

4 DNA I

Adam T. Woolley, Brigham Young University (United States)

5 DNA II

Heather D. Maynard, University of California, Los Angeles (United States)

Adam T. Woolley, Brigham Young University (United States)

6 Biosensors II

Hooman Mohseni, Northwestern University (United States)

Sean Humbert, University of Maryland, College Park (United States)

$7 \quad$ Bio-inspired Devices and Systems

Sean Humbert, University of Maryland, College Park (United States)

8 Biosensors III

Gert Cauwenberghs, University of California, San Diego (United States)

Hooman Mohseni, Northwestern University (United States) 